BETSY WARLAND is a Vancouver writer who has published two books of poetry. She is presently finishing a long poem Serpent (W)rite. She is also an editor (In the Feminine, Horizons, The Dene Drum Dance) and was the initiator and coordinator of Women and Words/Les Femmes et les mots (Vancouver, 1983).

\title{
Far As the I Can See
}

\author{
BETSY WARLAND
}

FICTION: "The action of 'feigning' or inventing imaginary incidents, existences, states of things, etc., whether for the purpose of deception or otherwise... The species of literature which is concerned with the narration of imaginary events and the portraiture of imaginary characters."'

I sit at my typewriter. I write to you -imaginary reader. As your eyes lift these words off the page, I become the writer. The writer you imagine who created this fictionary - as you say Nicole, "my fictions were reality." And I wonder, who's eyes (I/s) have we been looking into; whom do we address? has our gender role as women writers been that of immaculate deception? Have we like the killdeer cried out and feigned a broken wing to distract the heavy-footed fathers from our nearby camouflaged nest? And what of these "realistic" fictions of ourselves which we have read for generations and found barely recognizable - are they not real to the men who have written them? Adam naming Eve. The f(r)iction being in their insistence to import their "real" into ours as superior, in fact, more authentic. How many times have men argued that women writers' characters aren't "believable"?

Was it indeed essential to become skilled at feigning broken wings, until this wave of feminism made us less vulnerable, no longer alone on open

\section{The Oxford English Dictionary}


pebble plain - our cries now of anger and delight? We write from the nest and this seems fictitious to the heavy-footed; his bird book (highly regarded for its accuracy) had theorized (another action of the imaginary) something entirely different. Even to ourselves we often seem fictitious and like the "uncivilized" who have never seen their image, do not recognize this figure in the photograph and so stand back and say "who/what is that?" We recognize the chicken, the tree, everything but ourselves - self-portraits an abstraction. Now behind the camera we look at each other, feminine figures of speech, gaze from our own $\mathrm{I} / \mathrm{s}$, make ourselves present in this species ["specere, to look at"] of literature. Seeing as never before - we write new things. Fiction and theory coming together while physics even admits there is no such thing as an objective observer. When we look we change both seer and the seen. Returning the gaze we are often afraid. We have so seldom looked in each other's I/s, so often eavesdropped on our own li(v)es.

Here we are, barely trusting fiction - how can we trust theory (these imaginings historically having reduced us even more)? I remember the great row four of us had (all writers \& feminists) over dinner about why was/wasn't theory a patriarchial form - me running to get the dictionary, THEORY: "Greek theoros, spectator, from theasthai, to observe, from thea, a viewing." Spectator sports? A room with a view? "Theatre" (thea) of the observe? "But we're writing a new kind of theory - fiction/theory." No mind and body split, the text embodying the viewing. Form being the frown line above your left brow, the dimple on your right cheek, the word made flesh, the tissue the text.

Theory having an eye for an I. A seeing ourselves, breaking of the Other's gaze, stepping 3rd, 2nd, 1st person into viewing with our own I/s. Seeing ourselves as primary sources. Speaking subjects who VIEw: "weid-, wisdom, history, story" our own hystery, stories, speak from our own point of view. What intimidates us? Is it fear of what we'll see? Better to remain secondary sources, un(i)dentified (me, you/2 or preferably she, her/3) blind mice, see how they run, they all run after the farmer's wife... blind leading the blind afraid of what we'll find. Invaded enough in every way, why hand over the blueprints too? 
Point of view usually she, her $/ 3$ and occasionally me as you/2, our I absent in theor ze. Our I our corpus callosum connecting right \& left brains the seer \& seen self-possessed. Virgins in the original meaning "belongingto-no-man."' A necessity to theorlze in the 1st person, give I witness accounts, if we are to exorcise our wounds, if we are to trust our own gaze. Theoretics/theorethics - hasn't it been another moral of the story, the right point of view? We don't need one more voice of authority defining our literary morals yet this theorizing is not apart from us it comes from within our own TEXTS: "teks-, tissue."

Fiction/theory right (associative, wandering) \& left (interpreter, constructive) brains in hemispheric harmony a bilingual conversation of viewer and viewee (I'm of two minds about this), not an either-or situation but $1 \& 3$ talking so 2 can make sense of her multiplicity - the mother within - this is not dualism but the dialogue of difference. A continual re-viewing of point of view.

We are still uneasy, afraid we'll be misunderstood, criticized for being "too academic", "too intellectual", "rarefied", "patriarchial". Too too. As feminist writers, should our texts be accessible to all women? Is this possible? How is this expectation different from universality - a concept that has obliterated class, race, difference of belief and us for generations? Are my I/s interchangeable with your? Do we see I to I? Hasn't the function and appeal of writing always been to see through another's eyes $(I / s)$, glimpse another's point of view?

Stepping into the I of the storm...

2. Nor Hall, The Moon and the Virgin (New York: Harper \& Row, 1980), p. 11. 
I dream of an arsonist setting my writing desk on fire. The dream occurs in my father's father's house. The water is frozen and I can't put it out. The arsonist had believed it held the only copy of my text. The desk self-extinguishes. This seems important to remember.

Going to pieces, this text lacks a COSMOLOGY: "order, cosmetic," this writing called FRAGMENTARY: "to break, from bhreg-." BHREG-: "to vote for (use a broken piece of tile as a ballot), suffrage." Piece of one's mind (I'd like to give you...), voting in a man's wor(l)d - pieces assume a whole we are most often outside of. We live in a state of constant INTERRUPTION: "inter, between $\grave{u}$ rumpere, to break." Sounds like a mother, sounds like "just a house wife" (unskilled labour), sounds like those of us who are considered "skilled" but still men interrupt what we're saying $98 \%$ more of the time than we interrupt them. ${ }^{3}$ Our lives chaotic by nature (the World Goddess' womb, Eros born out of) - between the breaks - we crack the code of Adam's Garden Grammar, our texts interrupting themselves to hear what is being said. Inter-rupt/inner-rupt our bodies the site of other's presence, between the breaks/between the lines, all the voices in our heads can women fictionalize the feminine?

3. Dale Spender, Man Made Language (London: Routledge \& Kegan Paul, 1980), p. 43. 
"You're just imagining things." Yes, we have been all along.

"Only imagination is real!" 4

And the killdeer affect - the killdeer is real, the "broken" wing a real strategy (the foot is heavy) - fiction is what we KNOw: "gno-, narrate." Yet fictions we write are unlike fictions men write. FICTION: "fingere, to touch, form, mold. See dheigh-." DHEIGH-: "clay" ladies. I opener: fiction in our hands is to touch ourselves/one another, question the mold, the form, incessantly interrupting the manologue. We view, we touch, this is an eye for an I - fiction/theory (tissue/text) a total body presence.

4. William Carlos Williams, Pictures from Breughel and Other Poems (New York: New Directions, 1962), p. 179. 